\title{
Thalliomelane, $\operatorname{TIMn}_{7.5}^{4+} \mathrm{Cu}_{0.5}^{2+} \mathrm{O}_{16}$, a new member of the coronadite group from the preglacial oxidation zone at Zalas, southern Poland
}

\author{
Bożena Golębiowska ${ }^{1, *}$, Adam Pieczka ${ }^{1, \uparrow}$, Maciej Zubko ${ }^{2,3}$, Andreas Voegelin $^{4}$, \\ Jörg GöTTLICHER ${ }^{5}$, AND GRZEGORZ RZEPA ${ }^{1}$
}

\author{
${ }^{1}$ Department of Mineralogy, Petrography and Geochemistry, AGH University of Science and Technology, Mickiewicza 30, 30-059 Kraków, Poland \\ ${ }^{2}$ Institute of Materials Engineering, University of Silesia in Katowice, 41-500 Chorzów, 75 Pułku Piechoty 1a, Poland \\ ${ }^{3}$ Faculty of Science, Department of Physics, University of Hradec Králové, Rokitanského 62, 500 03, Hradec Králové, Czech Republic \\ ${ }^{4}$ Department of Water Resources and Drinking Water, Eawag, Swiss Federal Institute of Aquatic Science and Technology, \\ Überlandstrasse 133, CH-8600 Dübendorf, Switzerland \\ ${ }^{5}$ Karlsruhe Institute of Technology, Institute for Photon Science and Synchrotron Radiation KIT Campus North, \\ Hermann-von-Helmholtz-Platz 1, D-76344 Eggenstein-Leopoldshafen, Germany
}

\begin{abstract}
Thalliomelane, a new member of the coronadite group (hollandite supergroup), was discovered at Zalas near Kraków in southern Poland (the southern margin of the Kraków-Silesia Monocline) in relics of a preglacial supergene mineralization disseminated in a fault breccia in Middle Jurassic sandy limestone. The mineralization formed at the expense of a sulfide assemblage, which was most likely the source of thallium, related to rejuvenation of Early-Paleozoic fault zones in the Sava phase of the Alpine orogeny. Thalliomelane occurs rarely and exclusively in the form of fibrous and highly porous tiny aggregates $<50 \mu \mathrm{m}$ in size that fill small fractures and voids in the sandy limestone host rock. Microprobe analyses based on $16 \mathrm{O}$ and 8 octahedral cations per formula unit resulted in the mean empirical formula $\left[\mathrm{Tl}_{0.77(10)} \mathrm{Ba}_{0.21(3)} \mathrm{K}_{0.03(1)} \mathrm{Na}_{0.01(0)} \mathrm{Pb}_{0.01(0)}\right]_{\Sigma_{1.03(7)}}\left[\mathrm{Mn}_{7.15(1)}^{4+} \mathrm{Cu}_{0.63(4)}^{2+} \mathrm{Co}_{0.08(3)}^{2+} \mathrm{Fe}_{0.06(3)}^{3+} \mathrm{Ni}_{0.03(1)}^{2+} \mathrm{Si}_{0.03(2)}\right.$ $\left.\mathrm{Mg}_{0.01(1)}\right]_{\Sigma 8}\left[\mathrm{O}_{15.67(24)}(\mathrm{OH})_{0.33(24)}\right]$, corresponding to the formula $\mathrm{Tl}\left(\mathrm{Mn}_{7.5}^{4+} \mathrm{Cu}_{0.5}^{2+}\right) \mathrm{O}_{16}$ for the thalliomelane end-member. The mineral crystallizes in the tetragonal system, space group $I 4 / \mathrm{m}$, and has unit-cell parameters $a=9.8664(12), c=2.8721(4) \AA, V=279.59(8) \AA^{3}, Z=1$. The crystal structure of thalliomelane, measured with 3D electron-diffraction, was refined to an $R_{1}$ index of $23.74 \%$. Thalliomelane has the hollandite-type structure. The $\mathrm{Mn}^{4+}$ cations, substituted by $\mathrm{Cu}^{2+}$ at an amount of $\sim 0.5$ apfu, are octahedrally coordinated by oxygen atoms. Four double chains of edge-sharing ( $\mathrm{Mn}, \mathrm{Cu}$ )-O octahedra share corners with each other to form tunnels along the [001] direction. $\mathrm{Tl}^{+}$cations are located in the tunnels, occupying partially the origin and center of the unit cell. The formation of thalliomelane was most probably connected to the weathering of a sulfide mineral assemblage under semi-arid to arid climate. It resulted in the release of $\mathrm{Tl}$ and other components of the mineralization into water under the influence of Cl-, Br-, and I-bearing brines and pore waters from the Carpathian flysch or from sediments of the Carpathian foredeep mobilized by compaction during the Sava phase. Via the interaction of these waters, the primary ores altered mainly into goethite, cuprite, malachite, Mn oxides of the coronadite type, with subordinate $\mathrm{Cu}$ sulfates, $\mathrm{Pb}$ arsenates, $\mathrm{Bi}$ oxy-chlorides, and traces of iodargyrite. This assemblage indicates oxidation at a progressively increasing $\mathrm{pH}$ of $\sim 8-10$ and Eh of the order of $+0.4-0.5 \mathrm{~V}$. In this setting, thalliomelane could have formed from a cryptomelane-type Mn oxide in contact with Tl-bearing aqueous solutions through Tl-for-K exchange over time.
\end{abstract}

Keywords: Thalliomelane, thallium, Mn oxide, hollandite supergroup, coronadite group, chemical composition, crystal structure, supergene Tl mineral

\section{INTRODUCTION}

The hollandite supergroup contains several manganese (Mn) and titanium (Ti) oxides, often referred to as tunnel oxides, which are divided into two groups: the coronadite group and priderite group, depending on the dominant tetravalent cation $\left(\mathrm{Mn}^{4+}\right.$ and $\mathrm{Ti}^{4+}$, respectively) in the octahedral sites (Biagioni et al. 2013). The general formula of these minerals may be written as either $\mathrm{A}^{2+}\left[\mathrm{M}_{6}^{4+} \mathrm{M}_{2}^{3+}\right] \mathrm{O}_{16}$ or $\mathrm{A}^{1+}\left[\mathrm{M}_{7}^{4+} \mathrm{M}^{3+}\right] \mathrm{O}_{16}$, or more rarely

* E-mail: goleb@agh.edu.pl

$\uparrow$ Orcid 0000-0002-2841-7313 as $\mathrm{A}^{2+}\left[\mathrm{M}_{7}^{4+} \mathrm{M}^{2+}\right] \mathrm{O}_{16}$ or $\mathrm{A}^{1+}\left[\mathrm{M}_{7.5}^{4+} \mathrm{M}_{0.5}^{2+}\right] \mathrm{O}_{16}$, where $\mathrm{A}^{1+, 2+}=$ large monovalent or divalent cations: $\mathrm{Na}, \mathrm{K}, \mathrm{Tl}$ (in thalliomelane), $\mathrm{Pb}$, $\mathrm{Ba}, \mathrm{Sr} ; \mathrm{M}^{2+}=\mathrm{Fe}$ and $\mathrm{Cu}$ (in thalliomelane); $\mathrm{M}^{3+}=\mathrm{Mn}, \mathrm{Fe}, \mathrm{Cr}$, $\mathrm{V}$; and $\mathrm{M}^{4+}=\mathrm{Mn}$ and $\mathrm{Ti}$ (Biagioni et al. 2013). Thalliomelane, ideally $\mathrm{Tl}\left(\mathrm{Mn}_{7.5}^{4+} \mathrm{Cu}_{0.5}^{2+}\right) \mathrm{O}_{16}$, is the fifth known supergene $\mathrm{Tl}$ mineral species besides avicennite, $\mathrm{Tl}_{2} \mathrm{O}_{3}$ (Karpova et al. 1958), dorallcharite, $(\mathrm{Tl}, \mathrm{K}) \mathrm{Fe}_{3}^{3+}\left(\mathrm{SO}_{4}\right)_{2}(\mathrm{OH})_{6}($ Balić-Žunić et al. 1994), lanmuchangite, $\mathrm{TlAl}\left(\mathrm{SO}_{4}\right)_{2} \cdot 12 \mathrm{H}_{2} \mathrm{O}$ (Daiyan et al. 2003), and thalliumpharmacosiderite, $\mathrm{TlFe}_{4}\left(\mathrm{AsO}_{4}\right)_{3}(\mathrm{OH})_{4} \cdot 4 \mathrm{H}_{2} \mathrm{O}$ (Rumsey et al. 2014). Four other $\mathrm{Tl}$ minerals related to oxygen: chrysothallite, $\mathrm{K}_{6} \mathrm{Cu}_{6} \mathrm{Tl}^{3+} \mathrm{Cl}_{17}(\mathrm{OH})_{4} \cdot \mathrm{H}_{2} \mathrm{O}$ (Pekov et al. 2013, 2015), markhininite, 
$\mathrm{TlBi}\left(\mathrm{SO}_{4}\right)_{2}$ (Filatov et al. 2013; Siidra et al. 2014a), karpovite, $\mathrm{Tl}_{2} \mathrm{VO}\left(\mathrm{SO}_{4}\right)_{2}\left(\mathrm{H}_{2} \mathrm{O}\right)$ (Vergasova et al. 2013; Siidra et al. 2014b), and evdokimovite, $\mathrm{Tl}_{4}(\mathrm{VO})_{3}\left(\mathrm{SO}_{4}\right)_{5}\left(\mathrm{H}_{2} \mathrm{O}\right)_{5}$ (Siidra et al. 2013, 2014c) are products of the crystallization of fumarole gas; the remaining from above $100 \mathrm{Tl}$ mineral species known so far are mainly sulfides, arseno- or antimono-sulfides related to hydrothermal activity. Thalliomelane and its name were approved by the Commission on New Minerals, Nomenclature and Classification of the International Mineralogical Association (IMA CNMNC), proposal 2019-055 (Gołębiowska et al. 2019). By analogy to cryptomelane and strontiomelane, two other minerals of the coronadite group, the name of the mineral indicates the main constituent $(\mathrm{Tl})$ and the affinity to dark-colored manganese oxides. The holotype thalliomelane is deposited in the collection of the Mineralogical Museum of the University of Wrocław (Faculty of Earth Sciences and Environmental Management, Institute of Geological Sciences, Mineralogical Museum, 50-205 Wrocław, Cybulskiego 30, Poland), with the catalog number MMWr IV8025.

\section{OCCURRENCE}

Thalliomelane was found in a fault breccia encrusted with supergene $\mathrm{Cu}$ minerals and iodargyrite, exposed in 2005 in the active rhyodacite quarry at the Zalas village near Kraków, southern Poland (latitude 50.08426, longitude 19.64441; Gołębiowska et al. 2010, 2015). The village is located $\sim 5 \mathrm{~km}$ south of Krzeszowice ( $20 \mathrm{~km}$ west of Kraków), in the southern margin of the Kraków-Silesia Monocline (KSM), which was formed during the Laramide orogeny from Triassic, Jurassic, and Cretaceous deposits. The southern part of the monocline is arranged as a system of horsts and grabens, resulting from the northward over thrusting of Carpathian flysch nappes in Paleogene during the Alpine orogeny. The basement of the monocline is built of Wend to Carboniferous sediments with numerous sequences of Upper Carboniferous and Permian volcanic rocks occasionally exposed at the surface. Zalas is known, first of all, for an abundant assemblage of Middle and
Upper Jurassic fossils, occurring within the cover of a Permian rhyodacite laccolith, 281(4) Ma old (Nawrocki et al. 2005), which is exploited in a large quarry. In 2005, quarrying operations exposed a small fault zone cutting the Middle Jurassic sandy limestone occurring in the rhyodacite capstone, with a fault breccia locally encrusted by subordinate hydrothermal and supergene mineralization. The mineralization was composed mainly of $\mathrm{Fe}$ and $\mathrm{Mn}$ oxides and hydroxides and malachite, with rare, minute relics of sulfides represented by chalcopyrite, covellite, Ag-enriched chalcocite, galena, pyrite, marcasite, and also native bismuth, associated with cuprite, mottramite, $\mathrm{Cu}$ sulfates, a $\mathrm{Pb}-\mathrm{Al}$ arsenate, $\mathrm{Bi}$ oxy-chlorides, and iodargyrite. The primary sulfide mineralization was related to rejuvenation of Early-Paleozoic fault zones in the Sava phase of the Alpine orogeny, cutting the ore-mineralized basement of the KSM, which later subjected intensive weathering under semi-arid and arid climate between the Oligocene and Middle Miocene (Gołębiowska et al. 2010, 2015).

\section{Physical Properties}

Thalliomelane was found in only one fragment of the encrusted breccia. It occurs outside the main mass of supergene encrustations, in the form of tiny aggregates $<50 \mu \mathrm{m}$ in size, filling small fractures and voids in the host sandy limestone. The texture of the fillings is fibrous (maximum thickness of the fibers is only $\sim 1-2 \mu \mathrm{m}$ ) and highly porous (Fig. 1). In spite of the nano-sized texture of the oxide, its fibers seem to be homogeneous. Streak, luster, hardness, cleavage, tenacity, and optical properties were not observed due to the fibrous texture of the crystallites. Density was not measured for the same reason; the density was calculated on the basis of the empirical composition of the type thalliomelane, and its unit-cell volume is 5.285 and $5.370 \mathrm{~g} / \mathrm{cm}^{3}$ for the ideal composition. Using the empirical formula and calculated density, the mean refractive index obtained from Gladstone-Dale relation (Mandarino 1979, 1981 ) is 2.61 , and ideal thalliomelane should have a mean refractive index of 2.68 .
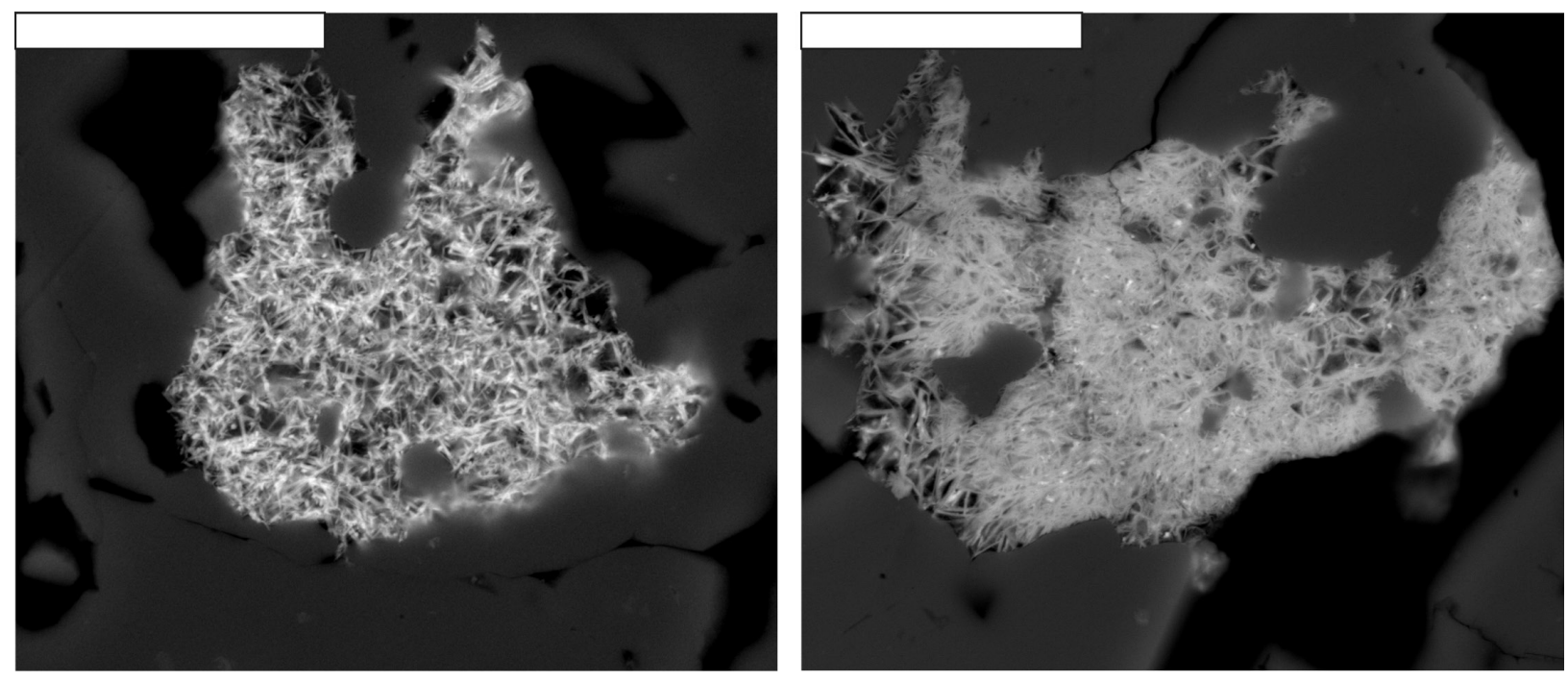

FigURE 1. Thalliomelane aggregates in Jurassic sandy limestone from Zalas. Scale bar $=10 \mu \mathrm{m}$. 

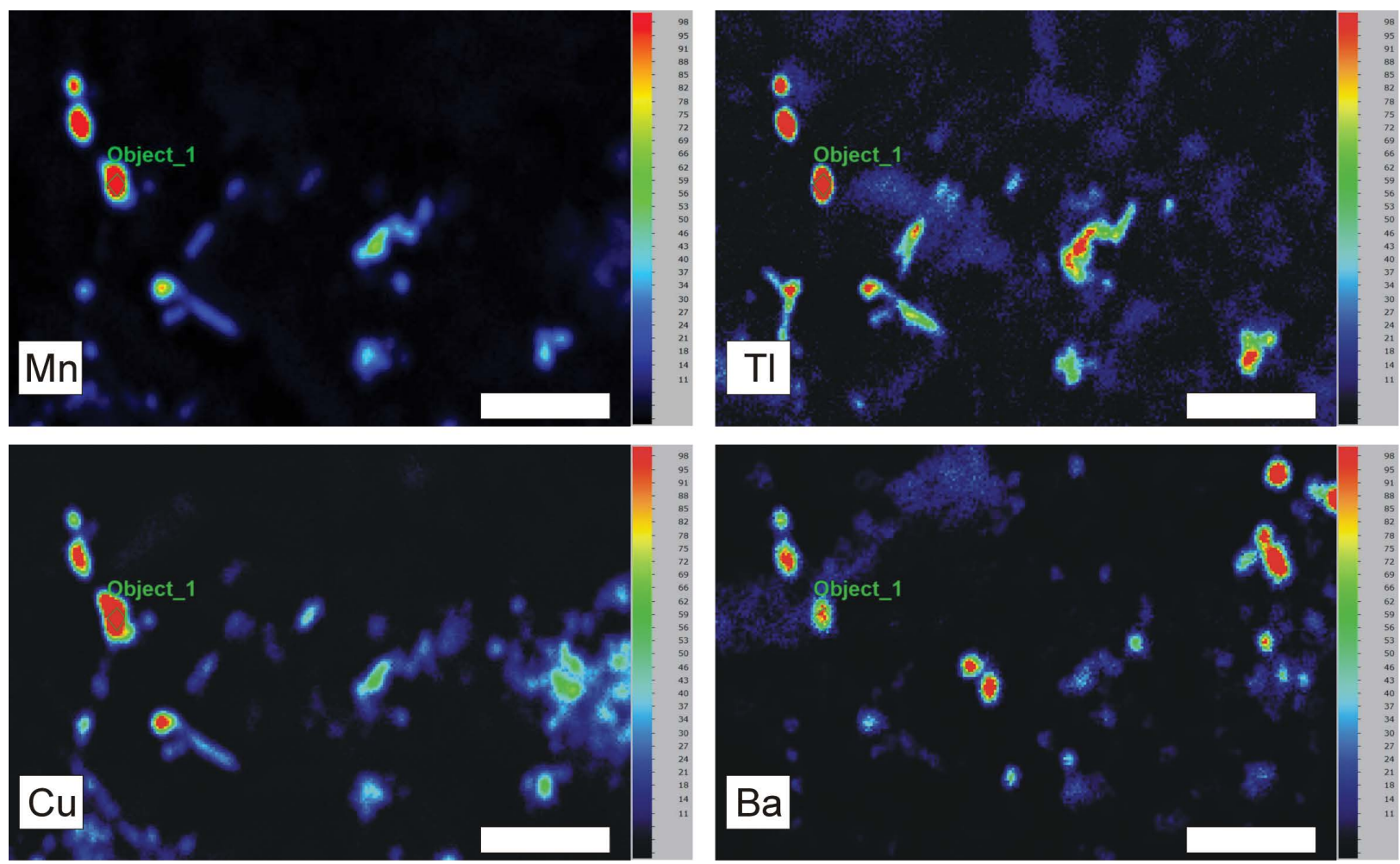

Figure 2. Micro-XRF element distribution maps around a selected (Tl,Mn)-rich particle (thalliomelane) in $\mathrm{CaCO}_{3}$ matrix $(\sim 25 \mu \mathrm{m}$ beam, step size $10 \mu \mathrm{m})$. Scale bar $=500 \mu \mathrm{m}$.

\section{MicRo-FOCUSED X-RAY FLUORESCENCE SPECTROMETRY ( $\mu$-XRF) AND X-RAY ABSORPTION SPECTROSCOPY ( $\mu$-XAS)}

A petrographic thin section containing a Tl-rich Mn-particle embedded in $\mathrm{CaCO}_{3}$ matrix was analyzed by $\mu$-XRF (Tornado M4, Bruker Nano GmbH; Ag X-ray tube; $25 \mu \mathrm{m}$ beam). Element distribution maps around a selected particle showed a clear correlation between $\mathrm{Mn}, \mathrm{Tl}, \mathrm{Cu}$, and $\mathrm{Ba}$ in the $\mathrm{Mn}$ oxide particle and an inverse correlation with $\mathrm{Ca}$ (Fig. 2). A semi-quantitative fundamental parameter analysis of the $\mu$-XRF spectrum integrated over the central part of the $\mathrm{Mn}$ oxide particle returned molar ratios of $0.06 \mathrm{Tl} / \mathrm{Mn}, 0.10 \mathrm{Cu} / \mathrm{Mn}$, and $0.03 \mathrm{Ba} / \mathrm{Mn}$. These values deviate somewhat from the ratios determined for thalliomelane based on electron probe micro-analysis (EPMA) on individual mineral grains $(0.11 \mathrm{Tl} / \mathrm{Mn}, 0.09 \mathrm{Cu} / \mathrm{Mn}, 0.03 \mathrm{Ba} / \mathrm{Mn}$; see the section "Chemical composition"). This deviation may be due to the semi-quantitative nature of the $\mu$-XRF quantification and the potential analyses of multiple $\mathrm{Mn}$ oxides within the analyzed zone (area of $\sim 45 \times 75 \mu \mathrm{m}^{2}$ with $\sim 25 \mu \mathrm{m} \mathrm{X-ray} \mathrm{beam).} \mathrm{On} \mathrm{the}$ other hand, the desktop $\mu$-XRF analysis is made on a selected $(\mathrm{Tl}, \mathrm{Mn})$-bearing particle, whereas EPMA analysis with results presented in Table 1 is an average of 14 spot analyses on different particles with the highest, but varying contents of $\mathrm{Tl}_{2} \mathrm{O}$.

$\mu$-XAS data at the Tl $L_{\mathrm{III}}$-edge and the $\mathrm{Cu}$ and $\mathrm{Mn} K$-edges of the Mn-rich particle were recorded at the SUL-X beamline of the Synchrotron Radiation Source of the Karlsruhe Institute of Technology, using a micro-focused X-ray beam with a size of $\sim 40 \times 40 \mu \mathrm{m}$. The spectra were recorded in fluorescence mode with a 7 -element $\mathrm{Si}(\mathrm{Li})$ solid-state detector. Comparison of the Tl $L_{\mathrm{III}}$-edge X-ray absorption near-edge structure (XANES) spectrum of the sample to the spectra of $\mathrm{Tl}_{2} \mathrm{O}_{3}$ and hydrated $\mathrm{Tl}^{+}$ as proxies for $\mathrm{Tl}^{3+}$ and $\mathrm{Tl}^{+}$clearly showed that $\mathrm{Tl}$ in the $\mathrm{Mn}$-rich particle is monovalent (Fig. 3a). Comparison of the $\mathrm{Cu} K$-edge XANES spectrum to reference spectra of $\mathrm{Cu}^{+}$and $\mathrm{Cu}^{2+}$ indicated that $\mathrm{Cu}$ was mainly present as $\mathrm{Cu}^{2+}$ (data not shown). The $\mathrm{Mn}$

TABLE 1. Chemical composition of thalliomelane

\begin{tabular}{lcccccc}
\hline Component & Mean (wt\%) & Range (wt\%) & S.D. (wt\%) & Ion & apfu & S.D. (apfu) \\
\hline $\mathrm{SiO}_{2}$ & 0.17 & $0.08-0.57$ & 0.14 & $\mathrm{Si}^{4+}$ & 0.025 & 0.021 \\
$\mathrm{MnO}_{2}$ & 67.23 & $65.02-68.85$ & 0.89 & $\mathrm{Mn}^{4+}$ & 7.154 & 0.115 \\
$\mathrm{Al}_{2} \mathrm{O}_{3}$ & 0.02 & b.d.I.-0.06 & 0.02 & $\mathrm{Al}^{3+}$ & 0.004 & 0.004 \\
$\mathrm{Fe}_{2} \mathrm{O}_{3}$ & 0.49 & $0.24 .-1.14$ & 0.25 & $\mathrm{Fe}^{3+}$ & 0.057 & 0.028 \\
$\mathrm{CoO}$ & 0.64 & $0.28 .-1.16$ & 0.32 & $\mathrm{Co}^{2+}$ & 0.079 & 0.034 \\
$\mathrm{NiO}$ & 0.23 & $0.15 .-0.30$ & 0.06 & $\mathrm{Ni}^{2+}$ & 0.028 & 0.006 \\
$\mathrm{MgO}$ & 0.05 & b.d.I.-0.12 & 0.04 & $\mathrm{Mg}^{2+}$ & 0.012 & 0.009 \\
$\mathrm{CuO}$ & 5.47 & $4.83-6.21$ & 0.47 & $\mathrm{Cu}^{2+}$ & 0.636 & 0.044 \\
$\mathrm{ZnO}$ & 0.04 & b.d.l.-0.15 & 0.04 & $\mathrm{Zn}^{2+}$ & 0.004 & 0.005 \\
$\mathrm{SrO}$ & 0.01 & b.d.I.-0.06 & 0.03 & $\mathrm{Sr}^{2+}$ & 0.001 & 0.002 \\
$\mathrm{BaO}$ & 3.53 & $2.89-4.39$ & 0.56 & $\mathrm{Ba}^{2+}$ & 0.213 & 0.032 \\
$\mathrm{PbO}$ & 0.14 & $0.06-0.20$ & 0.05 & $\mathrm{~Pb}^{2+}$ & 0.006 & 0.002 \\
$\mathrm{Na}_{2} \mathrm{O}$ & 0.04 & b.d.I.-0.06 & 0.01 & $\mathrm{Na}^{+}$ & 0.011 & 0.004 \\
$\mathrm{~K}_{2} \mathrm{O}$ & 0.14 & $0.08-0.20$ & 0.04 & $\mathrm{~K}^{+}$ & 0.027 & 0.007 \\
$\mathrm{Tl}_{2} \mathrm{O}$ & 17.67 & $15.18-20.83$ & 2.09 & $\mathrm{Tl}^{+}$ & 0.770 & 0.105 \\
$\mathrm{H}_{2} \mathrm{O}_{\text {calc }}$ & 0.32 & $0.00-0.70$ & 0.24 & $\mathrm{OH}^{-}$ & 0.332 & 0.236 \\
& & & & $\mathrm{O}^{2-}$ & 15.668 & 0.236 \\
Total & 96.19 & & & & & \\
\hline
\end{tabular}

Notes: Normalization of the analysis is made on the basis of $16(\mathrm{O}, \mathrm{OH})$ anions and 8 cations per formula unit; $\mathrm{H}_{2} \mathrm{O}_{\text {calc }}=$ calculated by charge balance.

${ }^{a}$ Mean analysis of thalliomelane is completed by an admixture of the host limestone $\left(1.82\right.$ wt $\% \mathrm{CaO}$ determined with EPMA and $1.43 \mathrm{wt} \% \mathrm{CO}_{2}$ calculated on the basis of calcite stoichiometry), which give the mean sum of components in the analyzed spots equal to $99.42 \mathrm{wt} \%$ (see explanations in the text). 
$K$-edge extended X-ray absorption fine structure (EXAFS) spectrum of the Mn-rich particle relatively closely matched the reference spectrum of hollandite and was clearly different from the reference spectra of triclinic birnessite and todorokite (Fig. 3b). This similarity pointed to a similar local Mn coordination in the Mn-rich particle as in the hollandite reference, in line with the identification based on 3D electron diffraction data of the Tl-rich $\mathrm{Mn}$-oxide mineral as a member of the coronadite group (see the section "Crystal structure").

\section{Chemical composition}

Electron probe micro-analyses of thalliomelane were performed at the Inter-Institute Analytical Complex for Minerals and Synthetic Substances at the University of Warsaw, Poland. The Cameca SX 100 electron microprobe was operated in wavelength-dispersive (WDS) mode with an accelerating voltage of $15 \mathrm{kV}$, a beam current of $20 \mathrm{nA}$, peak count-time of $20 \mathrm{~s}$, background time of $10 \mathrm{~s}$, and a beam diameter of 0 (focused) or $1 \mu \mathrm{m}$. Standards, analytical lines, diffracting crystals and mean detection limits ( $w \mathrm{t} \%$ element $)$ were as follows: albite $=\mathrm{Na}(K \alpha$, TAP, 0.02), $\mathrm{Al}(K \alpha, \mathrm{TAP}, 0.01)$, and $\mathrm{Si}(K \alpha, \mathrm{TAP}, 0.02)$; forsterite $=\mathrm{Mg}(K \alpha, \mathrm{TAP}, 0.01)$; orthoclase $=\mathrm{K}(K \alpha, \mathrm{PET}, 0.01)$; wollastonite $=\mathrm{Ca}(K \alpha, \mathrm{PET}, 0.02) ;$ rhodonite $=\mathrm{Mn}(K \alpha, \mathrm{LIF}, 0.05)$; hematite $=\mathrm{Fe}(K \alpha, \mathrm{LIF}, 0.05)$; cobaltite $=\mathrm{Co}(K \alpha, \mathrm{LIF}, 0.06) ; \mathrm{NiO}$ $=\mathrm{Ni}(K \alpha, \mathrm{LIF}, 0.04)$; cuprite $=\mathrm{Cu}(K \alpha, \mathrm{LIF}, 0.04)$; sphalerite $=$ $\mathrm{Zn}(K \alpha, \mathrm{LIF}, 0.06) ; \mathrm{SrSO}_{4}=\mathrm{Sr}(L \alpha, \mathrm{PET}, 0.03)$; baryte $=\mathrm{Ba}(L \alpha$,

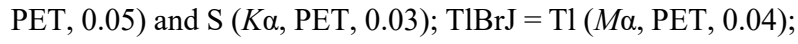
and galena $=\mathrm{Pb}(M \alpha, \mathrm{PET}, 0.03)$. The raw data were reduced with the PAP routine of Pouchou and Pichoir (1991) using the CAMECA software for the electron microprobe. From the 14 spot analyses with the highest $\mathrm{Tl}_{2} \mathrm{O}$ contents $(>15 \mathrm{wt} \%$; Gołębiowska
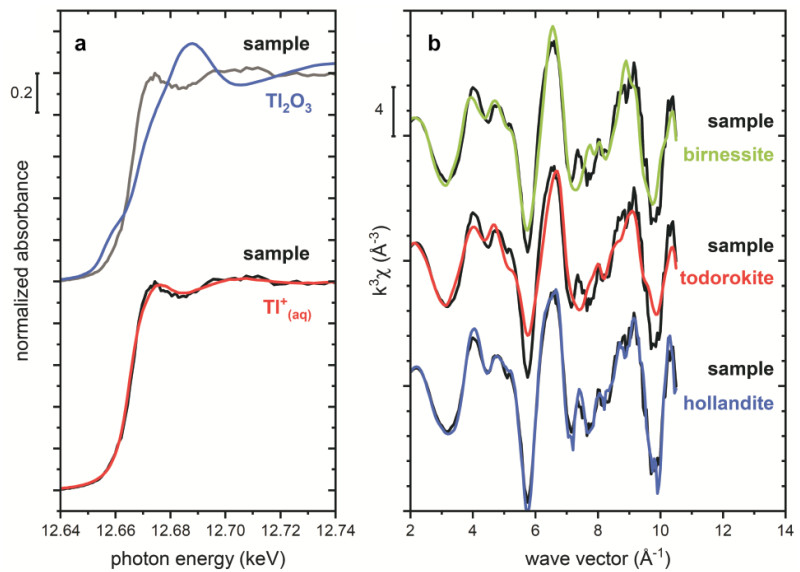

Figure 3. (a) $\mathrm{Tl} L_{\mathrm{III}}$-edge XANES spectrum of thalliomelane particle, the same as referred in Figure 2 (black lines) compared to reference spectra for $\mathrm{Tl}^{3+}\left[\mathrm{Tl}_{2} \mathrm{O}_{3}\right.$, blue line, from Voegelin et al. (2015) and $\mathrm{Tl}^{+}$ (aqueous $\mathrm{Tl}^{+}$, red line, from Wick et al. (2018)]; (b) Mn $K$-edge EXAFS spectrum of thalliomelane particle (black lines) compared to reference spectra of triclinic birnessite (green line), todorokite (red line), and hollandite (blue line). The reference spectra for triclinic birnessite and todorokite from Webb et al. (2005) were kindly provided by Sam Webb (Stanford Synchrotron Radiation Laboratory, Menlo Park, California, U.S.A.); the reference spectrum for hollandite from Manceau et al. (2007) was kindly provided by Alain Manceau (University of Grenoble, France). et al. 2015), the average empirical composition of thalliomelane was derived (Table 1). In our opinion, this procedure ensures the best comparability of the EPMA results with the composition of the mineral in the thin film that was prepared by focused ion beam (FIB) from a Tl-rich area [brightest in backscattered-electron (BSE) images], and that was used for 3D electron-diffraction structure refinement. In the formula calculation $\mathrm{Fe}$ was assumed to be trivalent, and $\mathrm{Co}, \mathrm{Ni}$, and $\mathrm{Cu}$ divalent based on the respective $\mathrm{pH}$-Eh diagrams of Takeno (2005). For the same reason, and based on the T1 $L_{\mathrm{III}}$-edge XANES spectrum of the (Tl,Mn)-oxide, which showed $\mathrm{Tl}$ to be mainly $\mathrm{Tl}(\mathrm{I})$, the valency +1 was assigned to Tl. Calcium determined by EPMA was excluded from the formula calculation because it correlates negatively with all main components of the oxide. It was considered as an admixture of $\mathrm{CaCO}_{3}$ from the host limestone. Therefore, $\mathrm{CaO}$ is mentioned in a note under Table 1 only as a microprobe-analyzed component but not as a constituent of the (T1,Mn)-oxide. Accordingly, a corresponding amount of $\mathrm{CO}_{2}$, in an atomic proportion equal to $\mathrm{Ca}$, was included as an additional component in the analytical spots that could not be analyzed by EPMA. Due to the scarcity of thalliomelane in the available sample and its microfibrolitic texture, IR spectroscopic confirmation of the presence of $\mathrm{H}_{2} \mathrm{O}$ was not possible. Tests to record the Raman spectrum of thalliomelane on its fibers were not successful because the mineral was not stable under the laser beam. Therefore, the empirical formula was calculated, considering the trace presence of $\mathrm{H}_{2} \mathrm{O}$ according to the coronadite-group stoichiometry, on the basis of $16(\mathrm{O}, \mathrm{OH})$ anions and 8 octahedral $\mathrm{M}$ cations per formula unit (Biagioni et al. 2013). The contents of elements along with analytical accuracies (sd; element standard deviation) are presented in Table 1, and the resulting empirical formula is $\left[\mathrm{Tl}_{0.77(10)} \mathrm{Ba}_{0.21(3)} \mathrm{K}_{0.03(1)}\right.$ $\left.\mathrm{Na}_{0.01(0)} \mathrm{Pb}_{0.01(0)}\right]_{\Sigma 1.03(7)}\left[\mathrm{Mn}_{7.15(11)}^{4+} \mathrm{Cu}_{0.63(4)}^{2+} \mathrm{Co}_{0.08(3)}^{2+} \mathrm{Fe}_{0.06(3)}^{3+} \mathrm{Ni}_{0.03(1)}^{2+} \mathrm{Si}_{0.03(2)}\right.$ $\left.\mathrm{Mg}_{0.01(1)}\right]_{\Sigma 8}\left[\mathrm{O}_{15.67(24)}(\mathrm{OH})_{0.33(24)}\right]$, which leads to the simplified formula of the thalliomelane mineral, $\left[(\mathrm{Tl}, \mathrm{K}), \mathrm{Ba}^{2+}\right]\left[(\mathrm{Mn}, \mathrm{Si})^{4+}\right.$, $\left.(\mathrm{Cu}, \mathrm{Co}, \mathrm{Ni})^{2+}\right]_{8}(\mathrm{O}, \mathrm{OH})_{16}$, and the respective end-member formula, $\mathrm{Tl}\left(\mathrm{Mn}_{7.5}^{4+} \mathrm{Cu}_{0.5}^{2+}\right) \mathrm{O}_{16}$. This end-member formula corresponds to (in wt\%) $23.49 \mathrm{Tl}_{2} \mathrm{O}, 72.11 \mathrm{MnO}_{2}$, and $4.40 \mathrm{CuO}$ (sum 100).

In the classification of Strunz (Strunz and Nickel 2001) thalliomelane occurs in class " 4 : OXIDES (Hydroxides, V[5,6] vanadates, arsenites, antimonites, bismuthites, sulfites, selenites, tellurites, iodates); D: Metal:Oxygen = 1:2 and similar; K: With large ( \pm medium-sized) cations; tunnel structures". In the classification of Dana (Gaines et al. 1997), it belongs to class "7: MULTIPLE OXIDES; 9: $\mathrm{AB}_{8} \mathrm{X}_{16}$."

\section{Crystal structure}

\section{Data collection and refinement}

Single-crystal X-ray diffraction studies could not be carried out because of the small cross section of the fibrous crystals of only $1-2 \mu \mathrm{m}^{2}$ and the very small amount of the available (Tl,Mn)bearing oxide. Therefore, the structural studies of thalliomelane were made applying $3 \mathrm{D}$ electron-diffraction using transmission electron microscopy (TEM). The studies were performed using a JEOL JEM 3010 instrument with $300 \mathrm{kV}$ accelerating voltage, equipped with $2 \mathrm{k} \times 2 \mathrm{k}$ OriusTM 833 SC200D Gatan CCD camera and Nanomegas Digistar electron beam precession attachment. For TEM analysis, a thin film from a Tl-rich por- 
tion of thalliomelane was prepared by focused ion beam (FIB) method using FEI Quanta 3D 200i scanning electron microscope (SEM) equipped with Ga ion gun. The TEM measurements aimed for crystal structure solution were performed using Precession Electron Diffraction method (Vincent and Midgley 1994; Gjönnes 1997; Kolb et al. 2007). The precession electron diffraction patterns were collected from $57^{\circ}$ angular range with $1^{\circ}$ step and $1^{\circ}$ precession angle. The acquisition time was $1 \mathrm{~s}$ per one electron diffraction pattern. The possible measurement range was limited by the fact that the studied crystal was partly shadowed by the specimen holder. The unit cell determination and data reduction were performed using PETS software (Palatinus et al. 2019) and further data analysis was performed using the software code Jana2006 (Petř́íček et al. 2014). After careful analysis of the symmetry, two possible space groups were chosen: $I 2 / \mathrm{m}$ or $I 4 / \mathrm{m}$. The first attempt to solve the crystal structure was undertaken in the higher symmetry space group. Structure solution procedure was performed with the charge flipping method using the SuperFlip software implemented in Jana2006. The initial model was refined, and missing atoms were found using Fourier maps analysis. Final refinement of the obtained model was performed using SHELXL software package (Sheldrick 2015 ), and the refinement converged at a $R 1$ value of $23.74 \%$. $\mathrm{X}$-ray powder diffraction data were not collected for the reasons presented above. However, TEM diffraction patterns (Table 2) were calculated for all observed reflections of the electron beam on the basis of the refined structural parameters.

\section{Structure description}

The details regarding the refined model of the thalliomelane structure (atom positions, selected interatomic distances) are

TABLE 2. TEM diffraction data ( $d$ in angstroms) for thalliomelane (only reflections with $I>1$ are presented)

\begin{tabular}{|c|c|c|c|c|c|}
\hline$I_{\text {meas }}$ & $D_{\text {calc }}$ & $h k l$ & $I_{\text {meas }}$ & $D_{\text {calc }}$ & $h k l$ \\
\hline 19 & 4.9332 & 020 & 8 & 1.2410 & 042 \\
\hline 85 & 3.1200 & 130 & 10 & 1.2333 & 080 \\
\hline 5 & 2.7576 & 011 & 4 & 1.2257 & $\overline{2} 71$ \\
\hline 39 & 2.4666 & 040 & 2 & 1.2257 & 271 \\
\hline 66 & 2.4071 & 121 & 2 & 1.2219 & 332 \\
\hline 10 & 2.4071 & $\overline{1} 21$ & 8 & 1.2035 & 242 \\
\hline 23 & 2.2062 & 240 & 9 & 1.1965 & 280 \\
\hline 66 & 2.1633 & 0331 & 3 & 1.1965 & $\overline{2} 80$ \\
\hline 25 & 1.9350 & 150 & 8 & 1.1532 & 152 \\
\hline 14 & 1.9350 & 150 & 6 & 1.1532 & 152 \\
\hline 45 & 1.8385 & $\overline{1} 41$ & 5 & 1.1470 & 570 \\
\hline 18 & 1.8385 & 141 & 3 & 1.1258 & 181 \\
\hline 5 & 1.6921 & 350 & 2 & 1.1258 & $\overline{1} 81$ \\
\hline 100 & 1.6444 & 060 & 2 & 1.1031 & 480 \\
\hline 4 & 1.6264 & 051 & 1 & 1.0949 & 352 \\
\hline 21 & 1.5600 & 260 & 14 & 1.0896 & 190 \\
\hline 39 & 1.5446 & 251 & 4 & 1.0896 & $\overline{1} 90$ \\
\hline 76 & 1.4361 & 002 & 24 & 1.0817 & 062 \\
\hline 10 & 1.4124 & $\overline{1} 61$ & 3 & 1.0715 & 381 \\
\hline 4 & 1.4124 & 161 & 5 & 1.0400 & 390 \\
\hline 6 & 1.4066 & 112 & 3 & 1.0242 & 091 \\
\hline 11 & 1.3953 & 170 & 6 & 1.0028 & $\overline{2} 91$ \\
\hline 1 & 1.3953 & $\overline{1} 70$ & 2 & 1.0028 & 671 \\
\hline 9 & 1.3788 & 022 & 1 & 1.0028 & 291 \\
\hline 2 & 1.3682 & 460 & 5 & 1.0073 & 172 \\
\hline 12 & 1.3578 & 451 & 2 & 0.9906 & 462 \\
\hline 3 & 1.3279 & 222 & 13 & 0.9866 & 0100 \\
\hline 3 & 1.3091 & 361 & 1 & 0.9827 & 581 \\
\hline 10 & 1.3045 & 132 & 7 & 0.9675 & $\overline{2} 100$ \\
\hline 4 & 1.3045 & $\overline{1} 32$ & 1 & 0.9675 & 2100 \\
\hline 10 & 1.2955 & 370 & 5 & 0.9619 & 372 \\
\hline 2 & 1.2653 & 071 & & & \\
\hline
\end{tabular}
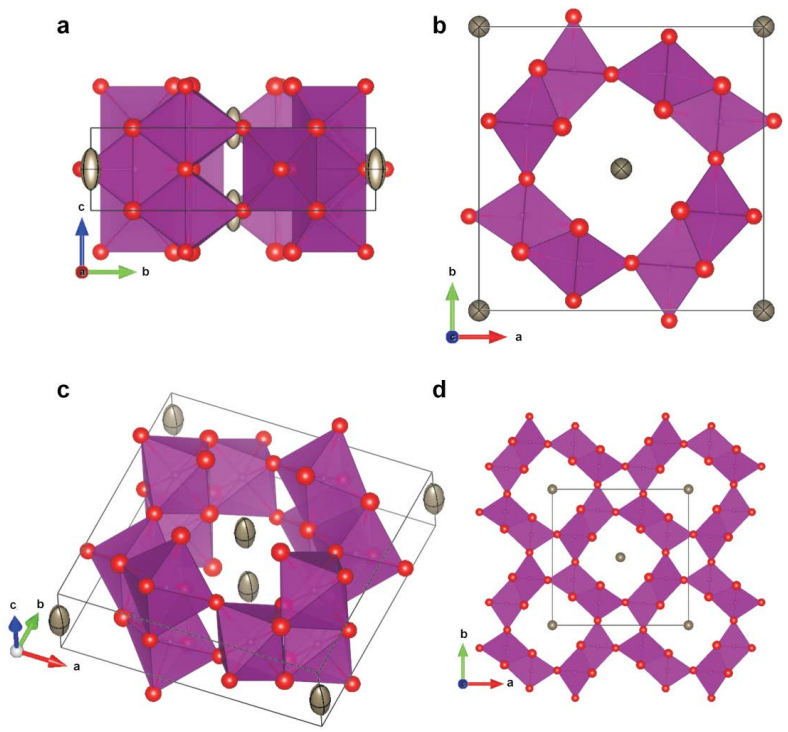

d

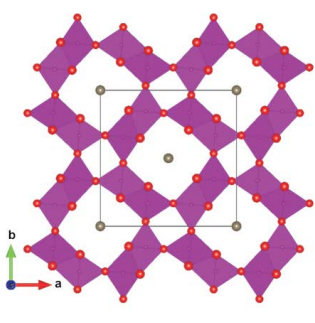

Figure 4. View of the crystal unit cell of thalliomelane along: (a) [100] direction, (b) [001] direction, (c) arbitrary direction, (d) [001] direction showing the channels in the structure. Symbols: $\left(\mathrm{Mn}^{4+}, \mathrm{Cu}^{2+}\right)$ octahedra are presented in violet color; red spheres = oxygen atoms; gray ellipses $=$ possible $\mathrm{Tl}$ positions.

listed in the CIF file attached as Online Materials ${ }^{1}$. Thalliomelane has tetragonal symmetry with the space group $I 4 / \mathrm{m}$. Unit-cell parameters are $a=9.8664(12), c=2.8721$ (4) $\AA$, and $V=279.59(8) \AA^{3}$ for $Z=1$. The resulting structural model of thalliomelane is similar to the hollandite structure. Divalent cations, represented in thalliomelane dominantly by $\mathrm{Cu}^{2+}$ at an amount of $\sim 0.5 \mathrm{apfu}$, are octahedrally coordinated by O. Four double chains of edge-sharing $\left(\mathrm{Mn}^{4+}, \mathrm{Cu}^{2+}\right)$-O octahedra share corners with each other to form tunnels along the [001] direction (Figs. $4 \mathrm{a}-4 \mathrm{~d}$ ). $\mathrm{Tl}^{+}$cations are located in the tunnels along the [001] direction. They occupy the origin and center of the unit cell. The refined $<M 1=(\mathrm{Mn}, \mathrm{Cu})-\mathrm{O}>$ bond length of $1.93(4)$ $\AA$ corresponds well to the bond length of $1.91 \AA$ calculated on the basis of Shannon's (1976) ionic radii of the complex $\mathrm{M} 1$ cation and $\mathrm{O}^{2-}$. Each $\mathrm{Tl}$ cation has eight neighboring $\mathrm{O}$ atoms creating cuboid-like coordination. The refined Tl-Tl distance (along the $c$-axis) of 2.8721(4) $\AA$ is shorter than the calculated ${ }^{\mathrm{VIII}} \mathrm{A}-{ }^{\mathrm{VIII}} \mathrm{A}$ distance $(2 \times 1.546 \AA=3.09 \AA)$ and the ideal ${ }^{\mathrm{VIII}} \mathrm{Tl}^{+}-{ }^{\mathrm{VIII}} \mathrm{Tl}^{+}$distance $(2 \times 1.59 \AA=3.18 \AA)$. As a result, the tunnel sites are occupied in the studied oxide only at $50 \%$. The $\mathrm{Tl}$ atomic displacement ellipsoids are elongated along the [001] direction, indicating a slight disorder of the oxygen anion positions in the tunnels. The $a: c$ ratio of thalliomelane calculated from unit-cell parameters, 1:0.291, is comparable to the values of analogous ratio in ferricoronadite 1:0.293, and manjiroite 1:0.289, two other members of the coronadite group with tetragonal symmetry (Table 3 ).

\section{GENETIC IMPLICATIONS}

The occurrence of thalliomelane, $\mathrm{TlMn}_{7.5}^{4+} \mathrm{Cu}_{0.5}^{2+} \mathrm{O}_{16}$, at Zalas, in close proximity to polymetallic encrustations with cuprite, malachite, and iodargyrite, suggests that $\mathrm{Tl}$ from a source in the 
TABLE 3. Comparative compositional and structural data for minerals of the coronadite group

\begin{tabular}{|c|c|c|c|c|c|c|c|c|}
\hline & Coronadite & Ferricoronadite & Hollandite & Ferriholandite & Cryptomelane & Manjiroite & Strontiomelane & Thalliomelane \\
\hline $\begin{array}{l}\text { Formula } \\
\text { Srystal }\end{array}$ & $\mathrm{Pb}\left(\mathrm{Mn}_{6}^{4+} \mathrm{Mn}_{2}^{3+}\right) \mathrm{O}_{16}$ & $\mathrm{~Pb}\left(\mathrm{Mn}_{6}^{4+} \mathrm{Fn}_{2}^{3+}\right) \mathrm{O}_{16}$ & $\mathrm{Ba}\left(\mathrm{Mn}_{6}^{4+} \mathrm{Mn}_{2}^{3+}\right) \mathrm{O}_{16}$ & $\mathrm{Ba}\left(\mathrm{Mn}_{6}^{4+} \mathrm{Fe}_{2}^{3+}\right) \mathrm{O}_{16}$ & $\mathrm{~K}\left(\mathrm{Mn}_{7}^{4+} \mathrm{Mn}^{3+}\right) \mathrm{O}_{16}$ & $\mathrm{Na}\left(\mathrm{Mn}_{7}^{4+} \mathrm{Mn}^{3+}\right) \mathrm{O}_{16}$ & $\mathrm{Sr}\left(\mathrm{Mn}_{6}^{4+} \mathrm{Mn}_{2}^{3+}\right) \mathrm{O}_{16}$ & $\mathrm{TIMn}_{7.5}^{4+} \mathrm{Cu}_{0.5}^{2+} \mathrm{O}_{16}$ \\
\hline $\begin{array}{l}\text { Crystal system } \\
\text { Space group }\end{array}$ & $\begin{array}{l}\text { Monoclinic } \\
12 / m\end{array}$ & $\begin{array}{c}\text { Tetragonal } \\
14 / m\end{array}$ & $\begin{array}{l}\text { Monoclinic } \\
12 / m\end{array}$ & $\begin{array}{l}\text { Monoclinic } \\
12 / m\end{array}$ & $\begin{array}{l}\text { Monoclinic } \\
12 / m\end{array}$ & $\begin{array}{l}\text { Tetragonal } \\
14 / m\end{array}$ & $\begin{array}{l}\text { Monoclinic } \\
12 / m\end{array}$ & $\begin{array}{c}\text { Tetragonal } \\
14 / m\end{array}$ \\
\hline$a(\AA)$ & $9.938(2)$ & $9.9043(7)$ & 10.026 & $10.0001(7)$ & 9.956 & 9.916 & $10.00(1)$ & $9.8664(12)$ \\
\hline$b(\AA ̊)$ & $2.8678(5)$ & $9.9043(7)$ & 2.878 & $5.7465(4)$ & 2.8705 & 9.916 & $5.758(7)$ & $9.8664(12)$ \\
\hline$c(\AA)$ & $9.834(2)$ & $2.8986(9)$ & 9.729 & $9.8076(8)$ & 9.706 & 2.864 & $9.881(1)$ & $2.8721(4)$ \\
\hline$\beta\left(^{\circ}\right)$ & $90.39(2)$ & 90 & 91.03 & $90.713(2)$ & 90.95 & 90 & $90.64(6)$ & 90 \\
\hline$V\left(\AA^{3}\right)$ & 280.26 & 284.34(9) & 279.48 & 563.36 & 277.35 & 281.61 & 568.85 & 279.59(8) \\
\hline Z & 1 & 1 & 1 & 2 & 1 & 1 & 2 & 1 \\
\hline$a: b: c$ & $3.465: 1: 3.429$ & 1:1:0.293 & $3.484: 1: 3.380$ & $1.740: 1: 1.707$ & $3.468: 1: 3.381$ & 1:1:0.289 & 1.737:1:1.716 & 1:1:0.291 \\
\hline Reference & $\begin{array}{l}\text { Post and } \\
\text { Bish (1989) }\end{array}$ & $\begin{array}{l}\text { Chukanov } \\
\text { et al. (2016) }\end{array}$ & $\begin{array}{l}\text { Post et al. } \\
\text { (1982) }\end{array}$ & $\begin{array}{l}\text { Biagioni } \\
\text { et al. (2014) }\end{array}$ & $\begin{array}{l}\text { Mathieson and } \\
\text { Wadsley (1950) }\end{array}$ & $\begin{array}{l}\text { Nambu and } \\
\text { Tanida (1967) }\end{array}$ & $\begin{array}{l}\text { Meisser } \\
\text { et al. (1999) }\end{array}$ & this study \\
\hline
\end{tabular}

KSM basement was transported along rejuvenated fault zones cutting the basement and deposited together with sulfide ores, which subsequently intensively weathered with the participation of saline fluids in semi-arid to arid climate. Weathering conditions of the primary ores and formation of the supergene assemblage with thalliomelane may be explained on the basis of thermodynamic stabilities of $\mathrm{Cu}$ and $\mathrm{Ag}$ minerals and dissolved $\mathrm{Cu}, \mathrm{Ag}, \mathrm{S}, \mathrm{Cl}, \mathrm{CO}_{2}$, and I species at $25^{\circ} \mathrm{C}$ and $p=1$ bar (Reich et al. 2009), supplemented by stabilities of $\mathrm{Tl}$ and $\mathrm{Mn}$ species in hydrous environments using the respective $\mathrm{pH}$-Eh diagrams of Brookins (1988), Vink (1993), and Takeno (2005).

The diagrams for thallium by Vink (1993) and Takeno (2005) suggest that over the entire range of $\mathrm{H}_{2} \mathrm{O}$ stability, $\mathrm{Tl}$ in water should occur primarily as monovalent $\mathrm{Tl}^{+}$cation. Although $\mathrm{Tl}^{+}$is considered to be the dominant $\mathrm{Tl}$ species, $\mathrm{Tl}^{3+}$ may occur under certain conditions, e.g., for example at a very high-Tl concentration, or due to stabilization in layered birnessite-type oxides (e.g., Bidoglio et al. 1993; Peacock and Moon 2012; Voegelin et al. 2015; Cruz-Hernández et al. 2019, 2020; Wick et al. 2019). Brookins (1988) considered that under oxidizing conditions, thallium oxides: $\mathrm{Tl}_{2} \mathrm{O}, \mathrm{Tl}_{2} \mathrm{O}_{3}$, and $\mathrm{Tl}_{2} \mathrm{O}_{4}$ dominate the Eh-pH space in order with increasing Eh, and only under strongly acidic oxidizing conditions $\mathrm{Tl}^{3+}$ appears. However, the $\mathrm{Tl} L_{\mathrm{II}}$-edge XANES spectrum of thalliomelane clearly shows that $\mathrm{Tl}$ is dominantly, if not entirely, monovalent $\mathrm{Tl}^{+}$. Moreover, we did not find $\mathrm{Tl}$, even in traces, in asbolane that associated relicts of the primary ores, and thalliomelane was found only in peripheral zone of the supergene encrustations. This location is easily explained by the high solubility of $\mathrm{TlOH}$ of $\sim 350 \mathrm{~g} / \mathrm{L}$ at $18{ }^{\circ} \mathrm{C}$ (Lin and Nriagu $1998)$ in contrast to the low solubility of $\mathrm{Tl}(\mathrm{OH})_{3}, \sim 0.8 \mu \mathrm{mol} / \mathrm{L}=$ $\sim 0.2 \mathrm{mg} / \mathrm{L}$ (Savenko 2000). Hence, rapid precipitation is unlikely, and $\mathrm{Tl}$ could migrate to areas more distant from the primary ores and other supergene components. The Eh-pH stability diagram of Reich et al. (2009) along with $\mathrm{Tl}$ and Mn data of Takeno (2005) indicates the most probable $\mathrm{pH}$ and Eh conditions during oxidation of the Zalas primary sulfides (Fig. 5). The sulfides [pyrite, marcasite, galena, chalcopyrite, Ag-bearing chalcocite, covellite, acanthite or (Ag,As)- or (Ag,Bi)-sulfosalts] formed most likely from hydrothermal solutions enriched in $\mathrm{H}_{2} \mathrm{~S}$ during rejuvenation of Paleozoic ore mineralization in the Sava phase of the Alpine orogeny. Then, the mineralization underwent oxidation in an arid climate, probably in the period between Late Oligocene to Mid Miocene (Gołębiowska et al. 2010). The oxidation typically formed, first, water dissolved species $\mathrm{Cu}^{+}$and $\mathrm{Cu}^{2+}, \mathrm{SO}_{4}^{2-}, \mathrm{Fe}^{2+}$, and $\mathrm{Fe}^{3+}$ with traces of $\mathrm{Mn}^{2+}$ and $\mathrm{Tl}^{+}$, and next, most likely, $\mathrm{Cu}$ and Fe sulfates, cuprite, and goethite; all found in the Zalas weathering suite. Interaction with the host Upper Jurassic sandy limestone resulted in increasing $\mathrm{pH}$ and crystallization of malachite. The rejuvenated fold zones could also have been migration paths for Cl-, Br-, and I-bearing brines and pore waters from the Carpathian flysch or from sediments of the Carpathian foredeep mobilized by compaction during the Sava phase (Gołębiowska et al. 2010). Passing up through the mineralization, the brines could

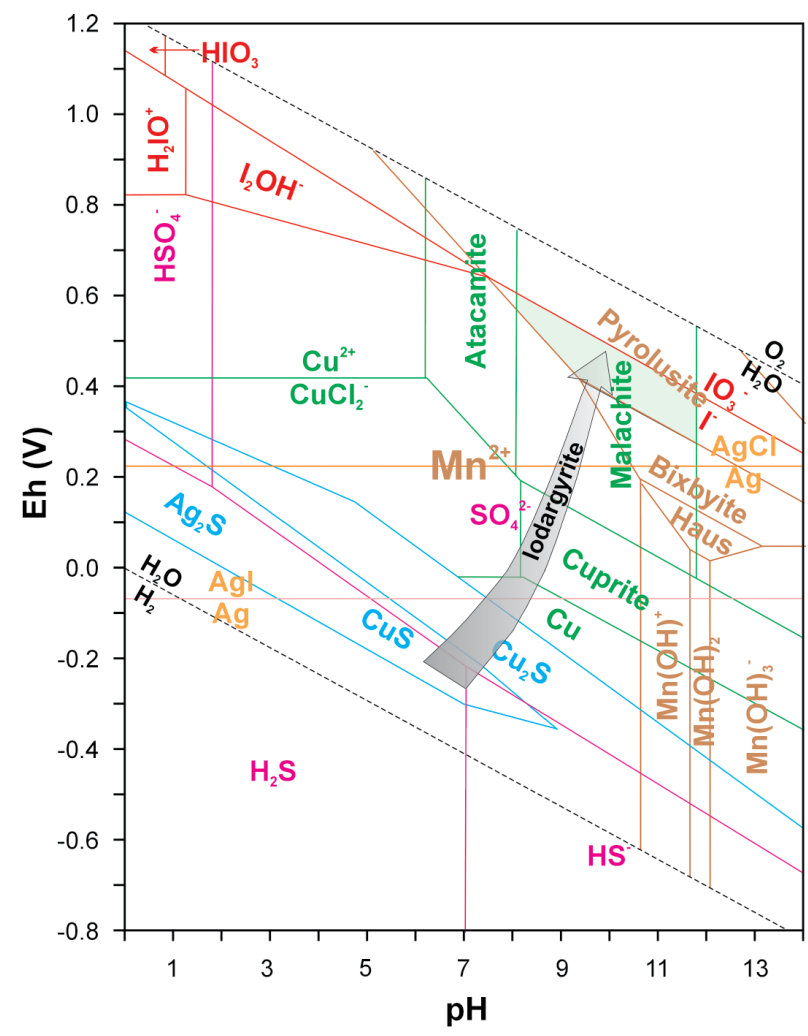

Figure 5. The pH-Eh diagram for the primary and supergene minerals at Zalas. Data for $\mathrm{Cu}$ and $\mathrm{Ag}$ minerals and dissolved species of $\mathrm{Cu}, \mathrm{Ag}, \mathrm{S}, \mathrm{Cl}, \mathrm{CO}_{2}$, and I are taken from Reich et al. (2009), data for Mn oxides and dissolved Mn species from Takeno (2005), $\mathrm{Tl}$ is not shown because at Zalas it precipitated along with $\mathrm{MnO}_{2}$ as $\mathrm{Tl}^{+}$, which corresponds to the stable Tl oxidation state over the $\mathrm{pH}$-Eh range of $\mathrm{H}_{2} \mathrm{O}$. Gray arrow marks a supposed $\mathrm{pH}$-Eh evolution path of the assemblage; greenish field corresponds to conditions under which thalliomelane could form, however due to direction of the changes in the $\mathrm{pH}$-Eh space the most probable conditions correspond to $\mathrm{pH} \sim 9-10$ and $\mathrm{Eh} \sim 0.4-0.5 \mathrm{~V}$. Abbreviations: Haus $=$ hausmannite. 
leach and transport away trace amounts of metals, most probably as halide and sulfate complexes. Another possible scenario may correspond to oxidation in arid periods with a deep-seated water table connected with the evaporation of salt lakes or a Neogene inland sea that delivered halide and sulfate ions to the groundwater oxidation system in the Early-Middle Miocene. The fluid chemistry is well documented by the presence of secondary $\mathrm{Cu}$ sulfates, $\mathrm{Bi}$ oxychlorides, and iodargyrite in the supergene products. In combination, these phases point to a high degree of evaporation and salination during the oxidation of the primary ores, and, by the co-presence of malachite and iodargyrite, an increased $\mathrm{pH}$ of $\sim 8-10$ (Gołębiowska et al. 2010) and Eh of the order of $+0.3-0.4 \mathrm{~V}$. Manganese could be mobilized from admixtures during oxidation of primary sulfides, e.g., from chalcopyrite and sphalerite. A further Eh increase may then have led to the immobilization of $\mathrm{Mn}$ by the precipitation of $\mathrm{Mn}^{4+}$ oxides. Primary $\mathrm{MnO}_{2}$ precipitates tend to be of nanocrystalline nature. Because of their high specific surface area and negative surface charge, they exhibit a very high-sorption capacity toward many trace cations such as $\mathrm{Pb}^{2+}, \mathrm{Cu}^{2+}, \mathrm{Co}^{2+}, \mathrm{Zn}^{2+}, \mathrm{Ni}^{2+}, \mathrm{Ba}^{2+}$, or $\mathrm{Sr}^{2+}$, e.g., Post et al. (1982) and Post (1999). The selective sorption of $\mathrm{Tl}$ onto $\mathrm{Mn}$ oxide in marine ferromanganese nodules usually results in Tl loadings of the order of $100 \mathrm{mg} / \mathrm{kg}$ (Peacock and Moon 2012), with higher Tl contents up to $675 \mathrm{mg} / \mathrm{kg}$ recorded in highly loaded deposits (Haynes et al. 1985; Koschinsky and Hein 2003; Hein et al. 2012). Data on Tl concentrations in individual Mn oxides are scarce. Crittenden et al. (1962) noted up to $3700 \mathrm{mg} \mathrm{Tl} / \mathrm{kg}$ in hollandite-cryptomelane from the Apache Mine in Arizona. Other examples of Tl-bearing Mn oxides include a psilomelane from Central Kazakhstan (up to $1000 \mathrm{mg}$ Tl/kg; Voskresenskaya and Soboleva 1961), cryptomelane from natural black pigments (up to $2000 \mathrm{mg} \mathrm{Tl} / \mathrm{kg}$; Jezequel et al. 2011), and hollandite from the Black Canyon shaft, New Mexico, U.S.A. (up to $5000 \mathrm{mg} \mathrm{Tl} / \mathrm{kg}$; Hewett 1968), and this is probably the highest $\mathrm{Tl}$ content found in any $\mathrm{Mn}$ oxide to date except that at Zalas. Similarly, high level of Tl enrichment in the $\mathrm{MnO}_{2}$ oxides from Zalas was noted in Cu-bearing coronadite $\left[0.36-0.51 \mathrm{Tl}_{2} \mathrm{O}\right.$ wt $\%$, i.e., $~ 3560-4900 \mathrm{mg} \mathrm{Tl} / \mathrm{kg}$; Gołębiowska et al. (2015)]. The variations in $\mathrm{Tl}$ loadings can be related to differences in $\mathrm{Mn}$ oxide structure and $\mathrm{Tl}$ uptake capacity, as well as to differences in dissolved $\mathrm{Tl}$ concentrations during $\mathrm{Tl}$ uptake.

In Mn oxides from Zalas, high contents of $\mathrm{Tl}, \mathrm{Cu}, \mathrm{Co}, \mathrm{Ni}$, and $\mathrm{Pb}$ suggest their direct relation with the primary ore assemblage. The oxides are mainly represented by coronadite-group minerals, including thalliomelane. Thalliomelane formed probably at conditions typical for $\mathrm{MnO}_{2}$ precipitates with the highest Eh potential marked in the assemblage, reaching $+0.5-0.6 \mathrm{~V}$ at the previously mentioned $\mathrm{pH}$ values (Fig. 5). Above the Eh, according to the stability diagram of I (Brookins 1988; Takeno 2005), iodides oxidize to iodates, which were not found at Zalas.

In a recent study on the sorption of $\mathrm{Tl}$ onto various Mn oxides (Wick et al. 2019), it has been shown that hexagonal vacancycontaining birnessite can sorb Tl by oxidation and complexation. In contrast, triclinic birnessite, as well as todorokite, were observed to sorb hydrated $\mathrm{Tl}^{+}$in their interlayers or tunnels without oxidation. Synthetic cryptomelane was found to sorb high levels of dehydrated $\mathrm{Tl}^{+}$by exchange of structural $\mathrm{K}$; with the replacement of up to $\sim 1 / 3$ of the initial $\mathrm{K}$. While this exchange process was not studied in detail with respect to cation exchange selectivity or limits of structural exchange, it is probable that the extent of Tl-for-K exchange depends on the dissolved concentrations of $\mathrm{Tl}^{+}$and $\mathrm{K}^{+}$as well as on structural factors, as reported for the uptake of $\mathrm{Rb}^{+}$and $\mathrm{Cs}^{+}$by cryptomelane (Tsuji and Komarneni 1993; Tsuji et al. 1993). Thus, we speculate that thalliomelane at Zalas could have formed from a cryptomelane-type precursor phase exposed to Tl-enriched fluids via gradual Tl-for-K exchange over extended periods of time. However, to constrain the potential pathways for thalliomelane formation, further insights into Tl-for-K exchange in cryptomelane and into the reactions of Tl with other Mn oxides are needed, as well as further mineralogical observations on the occurrence of thalliomelane or other Tl-bearing Mn-oxides in natural settings.

\section{ACKNOWLEDGMENTS AND Funding}

We thank Sergey Krivovichev, an anonymous reviewer, and the technical reviewer for their comments that were very helpful in improving the manuscript. We also thank Marta Gajewska (ACMiN, AGH UST, Kraków, Poland) for preparing a thin film (FIB method), Ralph Steininger (KIT, Germany) for his support during XAS data collection, and Sam Webb (Stanford Synchrotron Radiation Laboratory, Menlo Park, California, U.S.A.) and Alain Manceau (University of Grenoble, France) for sharing XAS reference spectra of Mn oxides. This study was financially supported by the AGH UST Grant 16.16.140.315 to B.G.

\section{REFERENCES CITED}

Balić-Žunić, T., Moëlo, Y., Lončar, Ž., and Micheelsen, H. (1994) Dorallcharite, $\mathrm{Tl}_{0,8} \mathrm{~K}_{0,2} \mathrm{Fe}_{3}\left(\mathrm{SO}_{4}\right)_{2}(\mathrm{OH})_{6}$, a new mineral of the jarosite-alunite family. European Journal of Mineralogy, 6, 255-263.

Biagioni, C., Capalbo, C., and Pasero, M. (2013) Nomenclature tunings in the hollandite supergroup. European Journal of Mineralogy, 25, 85-90.

Biagioni, C., Capalbo, C., Lezzerini, M., and Pasero, M. (2014) Ferrihollandite, $\mathrm{BaMn}_{6}^{4+} \mathrm{Fe}_{2}^{3+} \mathrm{O}_{16}$, from Apuan Alps, Tuscany, Italy. European Journal of Mineralogy, 26, 171-178.

Bidoglio, G., Gibson, P.N., O’Gorman, M., and Roberts, K.J. (1993) X-ray absorption spectroscopy investigation of surface redox transformations of thallium and chromium on colloidal mineral oxides. Geochimica et Cosmochimica Acta, 57, 2389-2394.

Brookins, D.G. (1988) Eh-pH Diagrams for Geochemistry. Springer-Verlag Berlin. Chukanov, N.V., Aksenov, S.M., Jančev, S., Pekov, I.V., Göttlicher, J., Polekhovsky, Y.S., Rusakov, V.S., Nelyubina, Y.V., and Van, K.V. (2016) A new mineral species ferricoronadite, $\mathrm{Pb}\left[\mathrm{Mn}_{6}^{4+}\left(\mathrm{Fe}^{3+}, \mathrm{Mn}^{3+}\right)_{2}\right] \mathrm{O}_{16}$ : Mineralogical characterization, crystal chemistry and physical properties. Physics and Chemistry of Minerals, 43, 503-514.

Crittenden, M.S., Cuttitta, F., Rose, H.D., and Fleischer, M. (1962) Studies on manganese oxide minerals VI. Thallium in some manganese oxides. American Mineralogist, 47, 1461-1467.

Cruz-Hernández, Y., Villalobos, M., Marcus, M.A., Pi-Puig, T., Zanella, R., and Martínez-Villegas, N. (2019) Tl(I) sorption behavior on birnessite and its implications for mineral structural changes. Geochimica et Cosmochimica Acta, 248, 356-369.

Cruz-Hernández, Y., Göttlicher, J., Pi-Puig, T., Ruiz-García, M., Villalobos, M., and Voegelin, A. (2020) Mechanisms of Tl(I) sorption and structural effects on poorly crystalline birnessites as a function of $\mathrm{Tl}(\mathrm{I})$ concentration. GEOC 6; American Chemical Society Fall 2020, Virtual Meeting and EXPO, August $17-20$.

Daiyan, C., Guanxin, W., Zhenxi, Z., and Yuming, C. (2003) Lanmuchangite, a new thallium (hydrous) sulphate from Lanmuchang, Guizhou Province, China. Chinese Journal of Geochemistry, 22, 185-192.

Filatov, S.K., Vergasova, L.P., Siidra, O.I., Krivovichev, S.V., and Kretser, Y.L. (2013) Markhininite, IMA 2012-040. CNMNC Newsletter No. 15, February 2013, page 2. Mineralogical Magazine, 77, 1-12.

Gaines, R.V., Skinner, H.C., Foord, E.E., Mason, B., and Rosenzweig, A. (1997) Dana's New Mineralogy, 8th ed. Wiley, New York.

Gjönnes, K. (1997) On the integration of electron diffraction intensities in the Vincent-Midgley precession technique. Ultramicroscopy, 69, 1-11.

Gołębiowska, B., Pieczka, A., Rzepa, G., Matyszkiewicz, J., and Krajewski, M. (2010) Iodargyrite from Zalas (Cracow area, Poland) as an indicator of Oligocene-Miocene aridity in Central Europe. Palaeogeography, Palaeoclimatology, Palaeoecology, 296, 130-137.

Gołębiowska, B., Rzepa, G., and Pieczka, A. (2015) Exceptional Tl-bearing manganese oxides from Zalas, Kraków area, southern Poland. Mineralogia, 46, 3-17. Gołębiowska, B., Pieczka, A., Zubko, M., Voegelin, A., Göttlicher, J., and Rzepa, 
G. (2019) Thalliomelane, IMA 2019-055. CNMNC Newsletter No. 52. Mineralogical Magazine, $83,888$.

Haynes, B.W., Law, S.S., Barron, D.C., Kramer, G.W., Maeda, R., and Magyar, M.J. (1985) Pacific manganese nodules: characterization and processing. Bulletin of the United States Department of the Interior, Bureau of Mines, 679.

Hein, J.R., Conrad, T.A., Frank, M., Christl, M., and Sager, W.W. (2012) Coppernickel-rich, amalgamated ferromanganese crust-nodule deposits from Shatsky Rise, NW Pacific. Geochemistry, Geophysics, Geosystems, 13, https://doi. org/10.1029/2012GC004286.

Hewett, D.F. (1968) Silver in veins of hypogene manganese oxides. Geological Survey Circular, 553. U.S. Department of the Interior, Washington, D.C.

Jezequel, P., Wille, G., Bény, C., Delorme, F., Jean-Prost, V., Cottier, R., Breton, J., Duré, F., and Despriee, J. (2011) Characterization and origin of black and red Magdalenian pigments from Grottes de la Garenne (Valléemoyenne de la Creuse-France): A mineralogical and geochemical approach of the study of prehistorical paintings. Journal of Archaeological Science, 38, 1165-1172.

Karpova, K.N., Kon'kova, E.A., Larkin, E.D., and Savel'ev, V.F. (1958) Avicennite, a new mineral. Doklady Akademii Nauk Uzbekistan SSR, 2, 23-26 (in Russian).

Kolb, U., Gorelik, T., Kübel, C., Otten, M.T., and Hubert, D. (2007) Towards automated diffraction tomography: Part I-Data acquisition. Ultramicroscopy, $107,507-513$

Koschinsky, A., and Hein, J.R. (2003) Uptake of elements from seawater by ferromanganese crusts: solid phase associations and seawater speciation. Marine Geology, 198, 331-351.

Lin, T.S., and Nriagu, J. (1998) Revised hydrolysis constants for thallium(I) and thallium(III) and the environmental implications. Journal of the Air \& Waste Management Association, 48, 151-156.

Manceau, A., Kersten, M., Marcus, M.A., Geoffroy, N., and Granina, L. (2007) $\mathrm{Ba}$ and $\mathrm{Ni}$ speciation in a nodule of binary $\mathrm{Mn}$ oxide phase composition from Lake Baikal. Geochimica et Cosmochimica Acta, 71, 1967-1981.

Mandarino, J.A. (1979) The Gladstone-Dale relationship. Part III. Some general applications. Canadian Mineralogist, 17, 71-76.

(1981) The Gladstone-Dale relationship. Part IV. The compatibility concept and its application. Canadian Mineralogist, 19, 441-450.

Mathieson, A.M., and Wadsley, A.D. (1950) The crystal structure of cryptomelane. American Mineralogist, 35, 99-101.

Meisser, N., Perseil, E.A., Brugger, J., and Chiappero, P.J. (1999) Strontiomelane, $\mathrm{SrMn}_{6}^{4+} \mathrm{Mn}_{2}^{3+} \mathrm{O}_{16}$, a new mineral species of the cryptomelane group from St. Marcel-Praborna, Aosta Valley, Italy. Canadian Mineralogist, 37, 673-678.

Nambu, M., and Tanida, K. (1967) Manjiroite, a new manganese dioxide mineral, from Kohare Mine, Iwate Prefecture, Japan. The Journal of the Japanese Association of Mineralogists, Petrologists and Economic Geologists, 58, 39-54 (in Japanese).

Nawrocki, J., Polechońska, O., Lewandowska, A., and Werner, T. (2005) On the palaeomagnetic age of the Zalas laccolith (southern Poland). Acta Geologica Polonica, 55, 229-236.

Palatinus, L., Brázda, P., Jelínek, M., Hrdá, J., Steciuk, G., and Klementová, M. (2019) Specifics of the data processing of precession electron diffraction tomography data and their implementation in the program PETS2.0. Acta Crystallographica, B75, 512-522.

Peacock, C.L., and Moon, E.M. (2012) Oxidative scavenging of thallium by birnessite: Explanation for thallium enrichment and stable isotope fractionation in marine ferromanganese precipitates. Geochimica et Cosmochimica Acta, 84, 297-313.

Pekov, I.V., Zubkova, N.V., Belakovskiy, D.I., Vigasina, M.F., Sidorov, E.G., and Pushcharovsky, D.Y. (2013) Chrysothallite, IMA 2013-008. CNMNC Newsletter No. 16, August 2013, page 2702. Mineralogical Magazine, 77, 2695-2709.

Pekov, I.V., Zubkova, N.V., Belakovskiy, D.I., Yapaskurt, V.O., Vigasina, M.F., Lykova, I.S., Sidorov, E.G., and Pushcharovsky, D.Y. (2015) Chrysothallite $\mathrm{K}_{6} \mathrm{Cu}_{6} \mathrm{Tl}^{3+} \mathrm{Cl}_{17}(\mathrm{OH})_{4} \cdot \mathrm{H}_{2} \mathrm{O}$, a new mineral species from the Tolbachik volcano, Kamchatka, Russia. Mineralogical Magazine, 79, 365-376.

Petř́ček, V., Dušek, M., and Palatinus, L. (2014) Crystallographic computing system JANA2006: General features. Zeitschrift Für Kristallographie - Crystalline Materials, 229, 345-352.

Post, J.E. (1999) Manganese oxide minerals: Crystal structures and economic and environmental significance. Proceedings of the National Academy of Sciences, 96, 3447-3454.

Post, J.E., and Bish, D.L. (1989) Rietveld refinement of the coronadite structure. American Mineralogist, 74, 913-917.

Post, J.E., Von Dreele, R.B., and Buseck, P.R. (1982) Symmetry and cation displacements in hollandites: structure refinements of hollandite, cryptomelane and priderite. Acta Crystallographica, B38, 1056-1065.

Pouchou, J.-L., and Pichoir, F. (1991) Quantitative analysis of homogeneous or stratified microvolumes applying the model "PAP". In K.F.J. Heinrich and
D.E. Newbury, Eds., Electron Probe Quantitation, pp. 31-75. Plenum Press, New York.

Reich, M., Palacios, C., Alvear, M., Cameron, E.M., Leybourne, M.I., and Deditius, A. (2009) Iodine-rich waters involved in supergene enrichment of the Mantos de la Luna argentiferous copper deposit, Atacama Desert, Chile. Mineralium Deposita, 44, 719-722.

Rumsey, M.S., Mills, S.J., Spratt, J., Hay, D.G., and Farber, G. (2014) Thalliumpharmacosiderite, IMA 2013-124. CNMNC Newsletter No. 20, June 2014 page 553. Mineralogical Magazine, 78, 549-558.

Savenko, V.S. (2000) Solubility of thallium(III) hydroxide in aqueous solution. Russian Journal of Inorganic Chemistry, 45, 1619-1620.

Shannon, R.D. (1976) Revised effective ionic radii and systematic studies of interatomic distances in halides and chalcogenides. Acta Crystallographica, A32, 751-767.

Sheldrick, G.M. (2015) Crystal structure refinement with SHELXL. Acta Crystallographica, C71, 3-8.

Siidra, O.I., Vergasova, L.P., Kretser, Y.L., Polekhovsky, Y.S., Krivovichev, S.V., and Filatov, S.K. (2013) Evdokimovite, IMA 2013-041. CNMNC Newsletter No. 17, p. 2999. Mineralogical Magazine, 77, 2997-3005.

Siidra, O.I., Vergasova, L.P., Krivovichev, S.V., Kretser, Y.L., Zaitsev, A.N., and Filatov, S.K. (2014a) Unique thallium mineralization in the fumaroles of Tolbachik volcano. Mineralogical Magazine, 78, 1687-1698.

Siidra, O.I., Vergasova, L.P., Kretser, Y.L., Polekhovsky, Y.S., Filatov, S.K., and Krivovichev, S.V. (2014b) Unique thallium mineralization in the fumaroles of Tolbachik volcano, Kamchatka Peninsula, Russia. II. Karpovite, $\mathrm{Tl}_{2} \mathrm{VO}\left(\mathrm{SO}_{4}\right)_{2}\left(\mathrm{H}_{2} \mathrm{O}\right)$. Mineralogical Magazine, $78,1699-1709$.

(2014c) Unique thallium mineralization in the fumaroles of Tolbachik volcano, Kamchatka Peninsula, Russia. III. Evdokimovite, $\mathrm{Tl}_{4}(\mathrm{VO})_{3}\left(\mathrm{SO}_{4}\right)_{5}\left(\mathrm{H}_{2} \mathrm{O}\right)_{5}$. Mineralogical Magazine, 78, 1711-1724.

Strunz, H., and Nickel, E.H. (2001) Strunz Mineralogical Tables, 9th ed. Schweizerbart'sche Verlagsbuchhandlung, Stuttgart.

Takeno, N. (2005) Atlas of Eh-pH diagrams. Intercomparison of thermodynamic databases. National Institute of Advanced Industrial Science and Technology, Research Center for Deep Geological Environments. Geological Survey of Japan Open File Report No.419.

Tsuji, M., and Komarneni, S. (1993) Powder X-ray diffraction study of a cryptomelane-type manganic acid and its alkali cation exchanged forms. Journal of Materials Research, 8, 3145-3150.

Tsuji, M., Komarneni, S., and Abe, M. (1993) Ion-exchange selectivity for alkali metal ions on a cryptomelane-type hydrous manganese dioxide. Solvent Extraction and Ion Exchange, 11, 143-158.

Vergasova, L.P., Siidra, O.I., Kretser, Y.L., Polekhovsky, Y.S., Filatov, S.K., and Krivovichev, S.V. (2013) Karpovite, IMA 2013-040. CNMNC Newsletter No. 17, October 2013, page 2999. Mineralogical Magazine, 77, 2997-3005.

Vincent, R., and Midgley, P.A. (1994) Double conical beam-rocking system for measurement of integrated electron diffraction intensities. Ultramicroscopy, $53,271-282$.

Vink, B.W. (1993) The behaviour of thallium in the (sub)surface environment in terms of Eh and pH. Chemical Geology, 109, 119-123.

Voegelin, A., Pfenninger, N., Petrikis, J., Majzlan, J., Plötze, M., Senn, A.-C., Mangold, S., Steininger, R., and Göttlicher, J. (2015) Thallium speciation and extractability in a thallium- and arsenic-rich soil developed from mineralized carbonate rock. Environmental Science \& Technology, 49, 5390-5398.

Voskresenskaya, N.T., and Soboleva, L.T. (1961) Once more on thallium in manganese minerals. Geokhimiya, 3, 276-278 (in Russian with English summary).

Webb, S.M., Tebo, B.M., and Bargar, J.R. (2005) Structural characterization of biogenic Mn oxides produced in seawater by the marine Bacillus sp. strain SG-1. American Mineralogist, 90, 1342-1357.

Wick, S., Baeyens, B., Marques Fernandes, M., and Voegelin, A. (2018) Thallium adsorption onto illite. Environmental Science \& Technology, 52, 571-580.

Wick, S., Peña, J., and Voegelin, A. (2019) Thallium sorption onto manganese oxides. Environmental Science \& Technology, 53, 13168-13178.

MANUSCRIPT RECEIVED APRIL 26, 2020

MANUSCRIPT ACCEPTED DECEMBER 10, 2020

MANUSCRIPT HANDLED BY MAarten A.T.M. BROEKMANS

\section{Endnote:}

${ }^{1}$ Deposit item AM-21-127577, Online Materials. Deposit items are free to all readers and found on the MSA website, via the specific issue's Table of Contents (go to http:// www.minsocam.org/MSA/AmMin/TOC/2021/Dec2021_data/Dec2021_data.html). The CIF has been peer reviewed by our Technical Editors. 